\title{
Vulgar and Obscene Terms in Indonesian Song Lyrics \\ (The Reflection Language Creativity)
}

\author{
Dewi Kusumaningsih \\ Universitas Sebelas Maret \\ Surakarta, Indonesia \\ dewikusumaningsih71@gmail.com \\ Riyadi Santosa \\ Universitas Sebelas Maret \\ Surakarta, Indonesia \\ rst@uns.ac.id
}

\author{
Djatmika \\ Universitas Sebelas Maret \\ Surakarta, Indonesia \\ djatmika26@gmail.com \\ H.D. Edi Subroto \\ Universitas Sebelas Maret \\ Surakarta, Indonesia
}

\begin{abstract}
Language is dynamic, social, complex, and multimodal, patterned and purposive just as all these kids of behavior. It is characterized from the language creativity emerging in the society as both linguistics and social phenomena. This article brings out the phenomenon of vulgar terms used in Indonesian song lyrics which is pondered belonging as the social language creativity. This research aims to describe the variation of vulgar terms found in Indonesian song lyrics. It takes 50 titles of Indonesian songs popularized between 1998 up to 2017 as the data sources. The data collected comprised of vocabularies and other forms of linguistic unit containing the phenomena of romance, loving, husband and wife relationship and family. The application of content analysis in this article is directed efficiently to describe various kinds of vocabularies or terms representing those phenomena. It focuses mainly on the transformation of general vocabularies toward explicit vulgar and obscene. The research results show that there are variation vocabulary starting implied, express, than clearly explicit and vulgar of various vocabulary who refers to romance, husband and wife relationship, and family.
\end{abstract}

Keywords- vulgar, obscene. language social creativity

\section{INTRODUCTION}

Song lyrics literally belong as a creative text representation formed either as an imagination or emotive feeling of the composers. They turn into a more touchable sense by the complementing of musical note which melodies could create such particular rhythm turning as the core spirit of a song. Thus, sometimes the listeners of a song could drown themselves comprehending the depth of its meaning. For instance, a love song will particularly create a blissful emotion of a smile as if the listener could feel how it is to be carried away by love; as a sad song telling a feeling of yearning could influence the mood of its listeners. Dictions, either with an implicit or explicit meaning become the key of impression to give a spirit inside the songs.
It has been a general phenomenon happening in Indonesia that apparently the use of inappropriate vulgar lyrics embedded in numerous songs. There is no more the essence of aesthetics, but crude, illicit and immoral messages conveyed in many Indonesian song lyrics. It eventually urged Komisi Penyiaran Indonesia Daerah Jawa Tengah - KPID Jateng (Indonesian Commission of Broadcasting in the region of Central Java) issued a prohibition on distribution toward various songs representing vulgar ideas in their lyrics. There were found 43 songs warned by KPID and 6 others were given options of either being banned from publication or midnight broadcasted via electronic media of radio and televisions Those 6 songs containing vulgarism in their dictions consisted of these titles: Apa Saja Boleh (Anything to Give You); Hamil Duluan (What A Fuck Gives); Maafkan Kamu Hamil Duluan (Sorry After Fucking You); Pengin Dibolongi (Fuck Me); dan Mobil Bergoyang (Fucking in The Car).

Vulgar means as an obscene, abusive, protrude, cruddy, shameless, sleazy, porno and illicit (Tesaurus Afabetis Bahasa Indonesia, 2009). Those expression of vulgarism is attached by the composers to make an apparent sense of love relating to those having a relationship, husband and wife, the third person in affair, characterization of love, particular organs in conveying how intercourse happens conveyed in songs, special events and moments, circumstances and others. The lingual form expressed in vulgar words should have come from various reasons. It could be caused by a cultural life, politic, analogy or even language social creativity (Asoulin, 2013; Carter, 2015; Kinga \& István, 2012; Steels, 2016). One obvious thing drawn from this phenomenon is that those composers are in their high excitement of pursuing an effort to promote such ideas to attract people's attention stated that there are micro processes founded a language creativity influenced by the analysis of particular values inside the scope of Sociolinguistic. 
This article will discuss the phenomenon of vulgarism and obscene as the lingual form used in Indonesian song lyrics as the process of language social creativity. It aims to describe kinds of vulgarism obtained as the representation of social life relating to romance of love, relationship, romance of husband and wife and the life of family. The data source comprising of vulgar and obsece terms gained from those lyrics is seen as the real states of language (Santosa, 2017) including physical, logical and psychological state.

\section{METHODOLOGY}

The study is conducted applying qualitative paradigm. It comes as the result of consideration upon data source, data and data analysis. It mainly aims to describe the phenomenon of vulgarism in Indonesian song lyrics. The description is directed to expose the cultural phenomenon toward the readers (Santosa, 2017; Subroto, 1992; Sudaryanto, 2015).

It takes Indonesian song lyrics containing vulgar, protrude and obscene vocabularies as the object of study. There are 50 song taken as the data source, containing the representation of social-cultural life regarding to where the songs are composed. This is called as the location of study (Santosa, 2017, p. 50). The data taken purposively based on the aim of the study, comprise of words, phrases, clauses and other forms of lingual units categorized as vulgar and obscene.

Content analysis is applied to display kinds of vulgarism in the form of vocabularies or other lingual units gained from the data source (Santosa, 2017).

\section{FINDINGS}

The findings are directed to counter the problems based on the aim of study. They are presented below:

a. Lingual units of Indonesian song lyrics relating to romance of love

\section{Ingin bercinta}

(Wanting to make a love)

Maafkan aku mencintainya

(I am sorry, I love him)

Pacarku

(My sweety)

Kalau rindu bertemu

(So heart yearns no more)

Yank

(Babe)

Cintaku tanpamu bagaikan malam tiada berlalu

(An endless night is my love without you here)

Walau ku tahu kau ada yang memiliki tapi cintaku tetap untukmu

(Even if you have been tied up but I keep wanting to make you near)

Dibuai cinta betapa indahnya

(Love cradles me velvet)

Peluk aku dan sentuh cintaku
(Hug me tight, touch me)

Disini ada aku yang sayang padamu

(Here is my love for you the one and only)

$K u$ rindu saat-saat bersamamu

(I am missing the moments when we were in)

Ku masih sayang padamu

(I am still loving you)

Kau buat diriku selalu jatuh cinta

(You make me fall in love time by time)

Hatiku berkata ingin katakan cinta

(My heart yells out for love)

Sama kamu aku dicumbuin

(You flirted me, tasted me as a sweet cheery)

Kau berikan aku surga dunia

(You took me down into paradise)

Kusadari aku cinta padamu

(I can't lie I love the way you do to me)

Ingin bercinta denganku

(Love me)

Karena separuh aku, dirimu

(Half of me is you)

Ingin dekati peluk aku dan sentuh cintaku

(Come and get me)

Jantungku berdetak saat ku dekat dengannya

(My heart beats harder for love)

Bahwa kau juga mencintaiku

(Say you love me too)

Aku sayang kamu selamanya

(I love you forever more)

Sentuhlah dia tepat dihatinya

(Give a touch right in her heart)

Terimakasih cinta untuk segalanya

(You gave me everything)

Waktu kamu peluk diriku

(When you hold me close)

Waktu kamu kecup keningku

(When you kiss my face)

Bercumbu denganmu

(When my body lays close to yours)

Ku dimanjakanmu

(You dote me over)

Bercumbu rayu

(Fucked up)

Walau cinta satu jam saja

(Even it went by too fast)

Dibuai cinta betapa indahnya

(Love cradles tenderly sweet)

Genit-genit juga kecentilan

(I like it when you flirt me)

Keganjengan, gaya berlebihan

(Touched up over and over)

Kalau kamu memang sayang

(Prove it you love me)

Gairah cinta pun membara

(Take what's been your desire)

Kenangan yang indah, kisah kita

(Remember this everytime)

Perpisahan yang termanis

(The soft goodbye) 
Kalau minggu mengajak pacaran

(Meet me on Sunday)

Akhirnya aku pacaran

(We'll take time for love)

Berdua saling mencinta

(You and I are in a crazy love)

Mereka melepas rindu di pematang sawah

(Holding each other far across the land)

Ku ingin bersama berdua selamanya

(I want to be with you forever)

Sudah bermain cinta

(After all this time of making love)

Setelah hilang rasanya hilang pula cintanya

(All the satisfaction's gone with the feelings)

b. Lingual units of Indonesian song lyrics relating to affair

Selingkuhanmu

(She is in love with you)

Ikatan yang tersembunyi

(Concealed love)

Perselingkuhan ini

(What the hell this affair is)

Karena tak selamanya selingkuh itu indah

(It will not last forever)

Sebagai selingkuhanmu

(I am the second one)

Kuharus menjalani ikatan yang tersembunyi

(Beyond the curtain of truth)

Selingkuh

(The affair)

Kalau beristri dua

(If you sleep both with me and her)

Ingin kuulangi dosa yang terindah

(It's the most sin I want to take once again)

Izinkan aku untuk selingkuh

(Let me do this too, to taste another)

Kau putuskan tuk mendua

(Cause you go out with another)

Selingkuh di belakangku

(Letting me dumb, you get another)

Mengapa mudahnya hatimu mendua

(How could you give another piece of you)

Ku jadi selingkuh, karena kau selingkuh

(You cheat since I do)

Kau penghianat cinta

(You're a love abuser)

c. Lingual units of Indonesian song lyrics relating to man and woman

Bapakku dengan seorang penghianat

(Father, you go out with the savage)

Hanya kekasih gelapku

(Only my secret love)

Dengan seorang

(With the one)

Ku diantara kalian

(I am between you two)
Foto siapa di dompetmu

(Who's this in the picture of your wallet)

Tak betah bila ada yang lain

(I can't stay with the lie)

Tak mudah kau bodohiku

(You can never fool me)

Di setiap ada kamu mengapa darahku mengalir

(My blood runs over whenever I'm with you)

Abang pilih yang mana perawan atau janda

(Either a girl or widow you choose, babe)

Siapa dirinya

(Who's he)

Walau ku tahu bahwa dirimu sudah ada yang punya, namun kan kutunggu sampai kau mau

(Even if you're with him, I'll keep waiting on you)

Karena kau telah memilih dia

(Since you want to be with him)

Karena ku masih mencintainya

(I still love him)

Ku bukan cewek murahan

(I am the badass)

d. Lingual units of Indonesian song lyrics relating to particular organs conveyed on how intercourse happens

Bila disentuh oleh lelaki

(If a man touches me)

Burung saya ada di sarang orang

(I surpass in her most hidden danger zone)

Keluar masuk lubang buaya

(Surpass the most danger zone)

Wangi aroma intim berdua

(I breathe you in, fuck you up)

Hilangkan wajahmu di hatiku

(Throw things about you out of my heart)

Lihat bodi semok pikiranmu jorok

(See, I am your body type on your mind)

e. Lingual units of Indonesian song lyrics relating to particular events or circumstances

Tapi dipukulin

(It's torturing)

Menjauhiku meninggalkanku

(Ignore, leave me)

Aku ingin engkau pergi

(Stay away from me)

Meninggalkan dirimu sayang

(Leave you, babe)

Baru kenal ngajak tidur

(Wanting to sleep with me since the first time)

Rangkul aku dalam bahagiamu

(Hug me in your happy mood)

Dekap aku dan hanyutkanku

(Brace myself, pull me down in your spell)

Peluk tubuhmu terangi aku disaat malam-malam gelap

(Your body is the light breaking down my nights)

Masang alat kontrasepsi

(Put the condom in) 
Aku terhanyut

(I am carried away)

Tapi aku puas rasanya

(I am feeling good after this moment)

Keluyuran, Cuma nampang doang

(Hanging out, to show off)

Jangan pelit-pelit sayang

(Don't take more time)

Sudah pasti lebih dewasa

(The satisfying one)

Pulang-pulangku berbadan dua

(You left this with me after we fucked up)

Ibuku minta cerai

(Mom tells about divorce)

\section{DISCUSSION}

Language social creativity found in those lyrics relates to love, affair, man and woman's relationship, particular organs told on how intercourse happens, events and circumstances. Every single lingual unit used in those lyrics has particular language characterization.

a. Lingual units of Indonesian song lyrics relating to romance of love

Its coherence relates to love which the lingual units are apparently conveyed. Below are the examples:

(1) Lingual units used to call a spouse

\author{
Yank (Babe) \\ Pacarku (My sweety) \\ Cintaku (My love) \\ Kekasih gelapku (My secret love) \\ Selingkuhanku/selingkuhanmu (My/your secret love)
}

The examples above are directed to the same meaning as they are used to call somebody to love. Some songs use the call of Yank (Babe), Pacarku (My sweety), and Cintaku (My love). Those calls point to someone who is in a relationship, husband or wife and family. However, there is found a form of vulgarism on the phrase kekasih gelapku (My secret love) and selingkuhanku/selingkuhanmu (My secret love). It is a kind of taboo, brutal and disdainful. It points to a meaning of humility for its referent.

(2) Lingual units to show romance

Kalau rindu bertemu

(So heart yearns no more)

Dibuai cinta

(Love cradles)

Rindu bertemu

(Heart yearns no more)

Dibuai cinta

(Love cradles)

Peluk aku
(Hug me)

Sentuh cintaku

(Touch me)

Aku dicumbui

(Flirted me)

Kau berikan aku surga dunia

(Take me down into your paradise)

Jantungku berdetak

(My heart beats harder)

Kamu peluk diriku

(When you hold me close)

Bercumbu denganmu

(When my body lays close to yours)

Bercumbu rayu

(Fucked up)

Melepas rindu di pematang sawah

(Holding each other far across the land)

Sudah bermain cinta

(After all this time of making love)

Cinta satu jam saja

(Love went by too fast)

There are obviously found some lingual units of the lyrics taken as data source, pointing to the activity of love making or romance. They are categorized as explicit and exposed in the case of vulgarism. There is no more conveying of the phrases pertemuan indah (sweet memory), kerinduan ini (I miss you), hasrat ini (this feeling) to convey how love is. This way, the composer has chosen a kind of vulgarism briefly to describe love with the referent of sex using some dictions including peluk (hug), cium (kiss), cumbu (flirt), gairah (desire), bercinta (fucking). Even, there are some clauses such as sudah bermain cinta (after all this time of making love), melepas rindu di pematang sawah (holding each other far across the land) and cinta satu jam saja (love went by too fast). Those indicate that the composers have ignored the true meaning of aesthetics in a song since the vulgarism attached. Below is the example of complete refrain of a particular Indonesian song lyric showing a vivid vulgarism:

Reff:

Satu jam saja bercumbu denganmu

(It was just a while you flirted me)

Satu jam saja ku dimanjakan

(It was just a while you dote me over)

Satu jam saja ku bercumbu rayu

(It was a while we fucked up)

Satu jam saja bercinta denganmu

(It was just a while we made a love)

It seems hyperbolic and categorized as a pornography which exists in some Indonesian song lyrics.

b. Lingual units of Indonesian Song Lyrics Relating to Affair

Affair is an illegal deed of having the third person as a spouse without having a confirmation of the other spouse 
legally married. It means as cheating (KUBI, 2012: 357). Thus, the meaning root of affair belongs to a dishonest, thus should not be conveyed in a song lyric. However, this phenomenon massively exists as a vulgarism in some Indonesian song lyrics. Below are the examples:

Selingkuhanmu
(Your secret love)
Ikatan yang tersembunyi
(Concealed love)
Kalau beristri dua
(If you sleep both with me and her)
Mengapa mudahnya hatimu mendua
(How could you give another piece of you)

The variations above save the same meaning that affair is conveyed implicitly using the phrases and clauses of ikatan yang tersembunyi (concealed love), kalau beristri dua (you sleep both with me and her), hatimu mendua (you give another piece of you). Those four data are categorized as implicit, explicit and exposed. The clause of Kalau beristri dua (if you sleep both with me and her) and phrase of Selingkuhanmu (yout secret love) are categorized explicit, while the clause Mengapa mudahnya hatimu mendua (how could you give another piece of you) and Ikatan yang tersembunyi (concealed love) are categorized as implicit. The term Selingkuhanmu (yout secret love) is a kind of vulgar meaning exposed apparently, even if it opposes the social norms for being illicit. Having an affair tends to break the social norms of marriage and is prohibited obviously in any kind of society. The existing term of selingkuh (affair) in song lyrics potentially create such a feeling of inconvenience of the listeners of Indonesian songs, however, this inappropriate thing precisely is exposed.

c. Lingual units of Indonesian song lyrics relating to the third person in romance

It is conveyed either explicit or implicit. Vulgarism always relates to the activities involving man and woman. It represents the role of man and woman in romance of love.

Hanya kekasih gelapku

(Only my secret love)

Dengan seorang

(With the one)

Ku diantara kalian

(I am betwen you two)

Foto siapa di dompetmu

(Who's this in the picture of your wallet)

Abang pilih yang mana perawan atau janda

(Either a girl or widow you choose, babe)

Di setiap ada kamu mengapa darahku mengalir

(My blood runs over whenever I'm with you)

Siapa dirinya

(Who's he)

Karena kau telah memilih dia

(Since you want to be with him)
They belong as a self-representation, others' relationship or husband and wife who comes into such illegal action of cheating. Those lyrics seem to state that everything is done because of love that cannot be hidden no more, thus is expressed by the terms of $K u$ di antara kalian (I am between you two), foto siapa di dompetmu (who's this in the picture of your wallet), siapa dirinya (who's he), kan kutunggu sampai kau mau (I'll keep waiting on you) and others. The over transparent exposure of the illegal relationship indicates that it seems to be something prevalent in society nowadays, especially youngsters. Thus, it triggers some specific discourses relating to it.

d. Lingual units of Indonesian song lyrics relating to particular organs conveyed on how intercourse happens

It is categorized as exposed. Below are the examples of obvious vulgarism found:
Bila disentuh oleh lelaki
(If a man touches me)
Burung saya ada di sarang orang
(I surpass in her most hidden danger zone)
Wangi aroma intim berdua
(I breathe you in, fuck you up)
Lihat bodi semok pikiranmu jorok
(See, I am your body type on your mind)

The prohibition issued by KPID toward the publication of some specific Indonesian songs containing obscene, illicit, protrude and triggering case of illegal sexual needs fulfillment should be supported as an effort to keep away from impoliteness. Some terms existing in Indonesian lyrics are distinguished as the form of vulgarism, such as burung (literaly means as penis) indicating male's sexual organ, bodi semok (sexy body) indicating a female's sexiness and disentuh lelaki (if a man touches me) belong as the representation of intercourse.

e. Lingual units of Indonesian song lyrics relating to events or circumstances

Mostly, it indicates something happen in romance or love. The vulgarism existing belongs as implicit and explicit.

Dekap aku dan hanyutkanku

(Brace myself, pull me down in your spell)

Peluk tubuhmu terangi aku disaat malam-malam gelap

(Your body is the light breaking down my nights)

Baru kenal ngajak tidur

(Wanting to sleep with me since the first time)

Masang alat kontrasepsi

(Put the condom in)

The use of implicit message in the song lyrics above indicates a brief vulgarism. The tendency that this 
phenomenon has been supposed to be as a preventive effect in the life of triggers is vulgarism will only sound inappropriate to be embedded in musical work. . This study is different from other writings about obscene forms written by other authors. There are not many special studies on obscene forms in language. Other studies more explain the use of language dirty by children (Hartmann, 1973). While the study of the influence of obscene forms of three dimensions of listener attitudes is raised by (Mulac, 1976). Results of the present study indicate that obscene language, which leads to the perception of lewdness, reduces perceived competence, trustworthiness, sociability (Hamilton, 1989). Another study written by (Fine \& Johnson, 1984) is about the motives of women and men to use obscenity

\section{Acknowledgment}

Acknowledgments of the authors to the linguists who have contributed in this paper. Many thanks to the descriptive UNS graduate linguistics staff who are very friendly and helpful writers. Also many thanks to the committee Inscription has given the author the opportunity to expression.

\section{References}

Asoulin, E. (2013). The creative aspect of language use and the implications for Linguistic Science. Biolinguistics, 7 , $228-248$.

Carter, R. (2015). Language and Creativity. Language and Creativity: The Art of Common Talk. https://doi.org/10.4324/9781315658971

Fine, M. G., \& Johnson, F. L. (1984). Female and male motives for using obscenity. Journal of Language and Social https://doi.org/10.1177/0261927X8431004

Hamilton, M. A. (1989). Reactions to obscene language. Communication Research Reports. https://doi.org/10.1080/08824098909359835

Hartmann, L. (1973). Some Uses of Dirty Words by Children. Journal of the American Academy of Child Psychiatry, 12(1), 108-122. https://doi.org/10.1097/00004583197301000-00008

Kinga, S., \& István, S. (2012). Relationship between Social Creativity and Social Intelligence, and their Cognitive Correlates. Transylvanian Journal of Psychology.

Mulac, A. (1976). Effects Of Obscene Language Upon Three Dimensions Of Listener Attitude. Communication Monographs. https://doi.org/10.1080/03637757609375941

Santosa, R. (2017). Metode Penelitian Kualitatif Kebahasaan. (D. Punanto, Ed.) (1, April 2 ed.). Surakarta: UNS Press.

Steels, L. (2016). Meaning and Creativity in Language. In CREATIVITY AND UNIVERSALITY IN LANGUAGE. https://doi.org/10.1007/978-3-319-24403-7_13

Subroto, D. E. (1992). Pengantar Metode Penelitian Linguistik Struktural (Pertama). Surakarta: UNS Press.

Sudaryanto. (2015). Metode dan Aneka Teknik Analisis Bahasa: Pengantar Penelitian Wahana Kebudayaan Secara Linguistis. Yogyakarta: Sanata Dharma University Press.

https://www.kpi.go.id/index.php/id/umum/38dalam-negeri/33922-kpid-jateng-larang-lagu-laguyang-dinilai-berbau-mesum-diputar-di-radio-dan-tv). 